\title{
Factors Affecting the Loan Loss Provision in Vietnamese System of Commercial Banks
}

\author{
NGUYẼ̃N THI THU HIỀN \\ University of Economics HCMC - hiendhkt@gmail.com \\ PHẠM ĐÌNH TUẤN \\ Nha Trang University - phamdinhtuanntu@yahoo.com.vn
}

\begin{tabular}{ll} 
ARTICLE INFO & ABSTRACT \\
\hline $\begin{array}{l}\text { Article history: } \\
\text { Received: } \\
\text { Dec. 23, 2013 }\end{array}$ & $\begin{array}{l}\text { Establishing loan loss provisions may affect bank's profitability and } \\
\text { capital adequacy ratio. The paper employs regression analysis to } \\
\text { explore operations of loan loss provisions in Vietnamese commercial } \\
\text { Received in revised form } \\
\text { June 03, 2014 }\end{array}$ \\
$\begin{array}{l}\text { banks in 2008-2012 in its relationship with bank characteristics. The } \\
\text { results show that loan loss provisions of Vietnamese commercial } \\
\text { Sep. 30, 2014 }\end{array}$ & $\begin{array}{l}\text { banks are positively related to size and proportion of bad debt and } \\
\text { negatively related to financial risk ratio. The paper provides }\end{array}$ \\
\hline $\begin{array}{l}\text { Keywords: } \\
\text { theoretical evidence of the opportunism in selection of accounting } \\
\text { provisions, loan loss losses }\end{array}$ & $\begin{array}{l}\text { policy concerning loan risk management by Vietnamese bank } \\
\text { managers. }\end{array}$
\end{tabular}




\section{INTRODUCTION}

Loans are the greatest asset, accounting for $50 \%$ to $75 \%$ of total assets and representing the biggest source of income for banks (MacDonald \& Koch, 2006). Yet, this kind of property also brings about risks when borrowers default on their debt. While managers usually set the highest level for loan loss provisions, accounting standard-setting bodies demand the presentation of loans with value that can be recovered. Moreover, to increase the corporate value, managers tend to establish flexible loan loss provisions (Gray \& Clarke, 2004); therefore, the measurement and reconsideration of determinants of loan loss provision must be the major concern of users of bank's financial statements.

Empirical researches on loan loss provisions and its determinants have been carried out in the world since the 1990s (Wall \& Koch, 2000). In Vietnam, there has not yet been one concerning this issue, whereas the information on commercial banks' bad debt disclosed by SBV's governor and inspectors and NFSC is dissimilar (Nguyễn, 2012). This research is to estimate loan loss provisions (LLP) of Vietnam's commercial banks in 2008-2012 and consider factors affecting LLP.

\section{THEORETICAL BASIS AND METHODOLOGY}

\subsection{Basic Concepts and Theories:}

\section{Loan losses and loan loss provisions}

Loan losses are risks occurring when a part of interest or principal or both interest and principal is not repaid as committed. Bank's existence and competitiveness are wholly dependent on abilities to control loan losses for profitability (Hampel \& Simonson, 2001). Despite the same attention to loan losses and loan loss provisions, managers and accounting standard-setting bodies have different goals. To ensure the safety of banking business, LLP is stipulated at the highest possible rate, while in light of information transparency, international accounting standards (IAS 39 - financial instruments: recognition \& measurement) demand to be based on objective evidence of signs of irrecoverable debts to determine loan losses and loss provisions.

As such, loan losses are the difference between book values of outstanding loans and present values of cash flows estimated to be received in the future. Loss values are included in overheads and reduce the value of loans through LLP entry. If the bank does not establish LLP, the values of loans on the financial statements will then include loan losses, which cause managers, creditors and investors to misunderstand 
and overestimate bank's equity. Accordingly, LLP is an accounting estimate, depending on the judgment of bank managers but affecting both business performance and financial status of the bank.

Signaling theory

Signaling theory initiated by Spence in 1973 is to explain the asymmetry of information in labor markets, but it is adopted by many accounting and finance researchers to clarify the problems of their research related to asymmetric information between managers and investors. By applying signaling theory, Ross (1977) argues that the existence of asymmetric information is considered to be the reason for wellrun companies to use their financial information and send market signals. Studies by Wahlen (1994), Beaver et al. (1989), and Beaver \& Engel (1996) suggest that LLP is enhanced by banks to arrange a signal for improved future cash flows. This research adopts the theory to explain how the ratio of equity to assets, financial risk coefficient and bank asset size affect the LLP.

Agency theory

The theory takes into account the relationship between principal and agent, that is, between shareholders and managers (Jensen \& Meckling, 1976). Agency theory is based on the existence of asymmetric information and conflicts of interest between principal and agent, resulting in agency costs (Levinthal, 1988). In 1997, US Security and Exchange Commission criticized banks that applied asset losses to profit management (Sutton, 1997). In LLP accounting, the theory is adopted to investigate the nexus between managers and creditors or shareholders to explain the formation of LLP based on an assumption of opportunism. In the research, this is used to explain how profit before taxes and provisions, and ratio of bad debt affect the LLP.

\subsection{Previous Studies:}

Since the First Basel Capital Accord (1988) was introduced and imposed requirements of minimum capital on banking business, there have been various studies on profit management and bank capital management as well as the use of LLP (Wahlen, 1994). In several countries, high judgment in determining LLP has allowed managers to maintain stable profit as expected (Kim \& Santomero, 1993) or reduce profit volatility (Ma, 1988). Studies on the use of LLP in capital management yield opposite results (Kanagaretnam et al., 2005). 
While Beatty et al. (1995) and Moyer (1990) conclude that LLP is employed among banks in capital management, Collins et al. (1995) come up with opposite results. The studies deem LLP a function with impacts of different variables concerning such bank's characteristics as business outcome and bad debt. In later periods, the variables' effects on LLP are demonstrated in studies by Hasan \& Wall (2004), Chen et al. (2005), Ashour (2011) and Mohd Yaziz (2011). Hasan \& Wall (2004) implement a fixed effects model to examine effects of bad debt, equity, earnings before tax and provision on LLP. Their findings signify that these factors all affect LLP, but the statistical significance among bank groups varies.

Through regression analysis, Chen et al. (2005) assume that apart from asset size, factors concerning sign and loss measurement all affect LLP. Ashour (2011) examines effects of profit before taxes and provisions, reserve fund, liability structure, capital adequacy ratio, loan to deposit ratio and total assets on LPP. The studies suggest certain evidence that banks reduce LLP when facing a shortage of required reserves and increased loan to deposit ratio. Mohd Yaziz (2011)'s adoption of fixed effects model is to explore factors affecting LLP of Malaysian banks during an economic crisis. The results signify that there is a lack of evidence to conclude that factors estimating bad debt recovery and bad debt have effects on LLP, but interest income and outstanding loan are positively correlated whereas profit are negatively correlated to the LLP.

\subsection{Research Model:}

The establishment of factors basically follows findings from previous studies. In addition, these selected factors are appropriate for LLP determination and could be easily measured for statistical analysis purposes.

\section{Dependent variable: $L L P$}

LLP, in most empirical researches, is measured by the ratio of the level of loan loss provisions to loan outstanding balance. While Chen et al. (2005) and Leventis et al. (2012) employ data as numerator and denominator at the time of financial statement establishment, Anandarajan et al. (2005) use average outstanding balance as the numerator. This research examines data of five years, distributed in various periods and thereby possibly reflects average fluctuations over years. 


$$
\text { LLP }=\frac{\text { Level of loan loss provisions }}{\text { Total loan outstanding balance }}
$$

\section{Independent Variables and Hypotheses}

Asset size (SIZE): Most studies have identified the variable SIZE measured by total assets affecting LLP. According to Chen et al. (2005), Ashour (2011) and Leventis et al. (2012), an increase in bank assets will expand credit operations, which potentially results in increased bad debt and rising LLP. First hypothesis is accordingly stated as below:

H1: Banks with larger asset size establish higher loan loss provisions than those with smaller one.

Asset size of banks is commonly large and it varies significantly across Vietnam's banks. Therefore, SIZE is selected as $\ln$ (total assets) to reduce dispersion by examining effect of every one-percent change in asset on LLP. Asset size (SIZE) $=\ln ($ total assets).

Ratio of equity to total assets (ER): ER is an indication of bank's capital adequacy and when being set at a low rate, equity should hardly be ensured in case of risks. Thus, as for low ER, banks have a tendency to reduce LLP in order to increase profit for increased equity (Hasan \& Wall, 2004). Regulations on capital adequacy ratio of Vietnam's commercial banks have gradually complied with international standards: Decision 457/2005/QĐ-NHNN set the capital adequacy rate at $8 \%$ according to Basel I and Circular 13/2005/QĐ-NHNN increased it to $9 \%$ as recommended by Basel II. Yet, in reality, only a small number of large banks can ensure capital adequacy as prescribed (Ngô, 2012) and banks with low ER tend to keep small LLPs to ensure the required capital adequacy ratio. The second hypothesis is consequently suggested as follows:

H2: Banks with low ratio of equity to previous year-end total assets build up loan loss provisions smaller than those with high ratios.

$$
\text { ER }=\frac{\text { Previous year-end equity }}{\text { Previous year-end total assets }}
$$


Bad Debt (NP): Bad (non-performing) debt is one of the root causes for bank's capital loss and affects cash flows in bank operations. As a result, this variable is included in models adopted by many studies such as Chen et al. (2005), Anandarajan et al. (2005), Hasan \& Wall (2004) and Pérez et al. (2008), which allows the formation of the third hypothesis:

H3: Bad debt positively impacts on loan loss provisions. An increase in bad debt correspondingly leads to increased loan loss provisions.

While Hasan \& Wall (2004), Perez et al. (2008) and Yeh (2010) measure NP by the ratio of bad debt to total assets, the others employ the ratio of bad debt to loan outstanding balance. The latter reflects the quality of lending items, whereas the former allows the quality of total assets to be evaluated. Hence, the research measures bad debt in both ways:

Ratio of bad debt to total loan outstanding balance (NP1)

$$
\mathrm{NP1}=\frac{\text { Bad debt }}{\text { Total loan outstanding balance }}
$$

Ratio of bad debt to total assets (NP2)

$$
\mathrm{NP2}=\frac{\text { Bad debt }}{\text { Total assets }}
$$

Earnings before tax and provision (CROA): Several empirical studies on profit management and LLP offer contrary conclusions: Collins et al. (1995), Beaver \& Engel (1996), and Ahmed et al. (1999) find no evidence of manipulation of income statements, whereas Wahlen (1994) provides striking evidence of the adoption of LLP in profit management. Fudenberg \& Tirole (1995) indicate that during tough times, managers would transfer profit in the future to that in the present through LLP. In Vietnam in the years 2006-2011, large banks have higher ratios of earnings before tax and provision to assets than smaller ones (Nguyễn \& Vũ, 2013). However, as for Ngô (2012), only a few large banks can possibly ensure capital adequacy. Banks with high CROA, which do not necessarily burden themselves with increased equity, will aim at improving quality of assets by establishing sufficient LLP. In contrast, those with low CROA tend to establish lower LLP because of their poor capital adequacy ratio. This formulates the fourth hypothesis: 
H4: Earnings before tax and provision have a positive correlation with loan loss provisions of commercial banks.

$$
\mathrm{CROA}=\frac{\text { Earnings before tax and provision }}{\text { Total assets }}
$$

Coefficient of financial risk (CE): $\mathrm{CE}$ is measured by the ratio of outstanding balance to total assets. Ashour (2011) suggests that there exists a negative relationship between CE and LLP, yet Perez et al. (2008) and Hasan \& Wall (2004) produce contrary findings. According to Nguyễn \& Vũ (2013), large banks have higher ratios of loan to assets and ratios of LLP to assets than smaller ones. The last hypothesis is proposed:

H5: Coefficient of financial risk is positively correlated with loan loss provision.

$$
\mathrm{CE}=\frac{\text { Total loan outstanding balance }}{\text { Total assets }}
$$

\subsection{Data and Methodology:}

\section{Data}

Data used in the research are collected from audited financial statements of 23 commercial banks with statements between 2008 and 2012 published in their websites.

Table 1. Lists of Commercial Banks

\begin{tabular}{cccccccc}
\hline No. & $\begin{array}{c}\text { Stock } \\
\text { code }\end{array}$ & $\begin{array}{c}\text { Stock } \\
\text { exchange }\end{array}$ & $\begin{array}{c}\text { Charter capital } \\
\text { (VND billion) }\end{array}$ & No. & Stock code & $\begin{array}{c}\text { Stock } \\
\text { exchange }\end{array}$ & $\begin{array}{c}\text { Charter capital } \\
\text { (VND billion) }\end{array}$ \\
\hline 1 & CTG & Hose & 32,661 & 13 & PNB & OTC & 4,000 \\
2 & VCB & Hose & 23,174 & 14 & MDB & OTC & 3,750 \\
3 & BID & Hose & 23,011 & 15 & Vietabank & OTC & 3,098 \\
4 & EIB & Hose & 12,355 & 16 & MHB & OTC & 3,055 \\
5 & STB & Hose & 10,740 & 17 & Saigonbank & OTC & 3040 \\
6 & MBB & Hose & 10,625 & 18 & NVB & HNX & 3,010 \\
7 & ACB & HNX & 9,377 & 19 & VietCapital bank & OTC & 3,000
\end{tabular}




\begin{tabular}{cccccccc}
8 & SHB & HNX & 8,865 & 20 & WEB & OTC & 3,000 \\
9 & VP Bank & OTC & 5,050 & 21 & Namabank & OTC & 3,000 \\
10 & DongAbank & OTC & 5,000 & 22 & Kienlongbank & OTC & 3,000 \\
11 & HDBank & OTC & 5,000 & 23 & PGBank & OTC & 3,000 \\
12 & Oceanbank & OTC & 4,000 & & & & \\
\hline
\end{tabular}

Source: SBV (June 30, 2013)

\section{Methodology}

Employing quantitative method and based on analyses from previous studies, this paper predicts the correlation between dependent and independent variables according to the following model:

$$
\mathrm{LLP}_{\mathrm{it}}=\alpha \mathrm{i}_{\mathrm{i}}+\beta_{1} \mathrm{SIZE}_{\mathrm{it}}+\beta_{2} \mathrm{ER}_{\mathrm{i}, \mathrm{t}-1}+\beta_{3} \mathrm{NP}_{1 \mathrm{it}}+\beta_{4} \mathrm{NP}_{2} \mathrm{~L}_{\mathrm{it}}+\beta_{5} \mathrm{CROA}_{\mathrm{it}}-\beta{ }_{6} \mathrm{CE}_{\mathrm{it}}+\mathrm{u}_{\mathrm{it}}
$$

Where:

$\mathrm{i}=1,2, \ldots, 23\left(\mathrm{i}^{\text {th }}\right.$ bank);

$\mathrm{t}=1,2, \ldots, 5$ (order of the years, from 2008 to 2012 );

LLP $_{\text {it: }}$ Ratio of LLP to total outstanding balance of bank $i$ at time $t$;

SIZE $_{\mathrm{it}}$ : Logarit of total assets of bank $i$ at time $t$;

ERi,t-1: Ratio of equity to total assets of bank $i$ at time $t$;

NP1it: Ratio of bad debt to total outstanding balance of bank $i$ at time $t$;

NP2 $\mathrm{L}_{\mathrm{it}}$ : Ratio of bad debt to total assets of bank $i$ at time $t$;

$\mathrm{CROA}_{\mathrm{it}}$ : Ratio of earnings before tax and provision to total assets of bank $i$ at time $t$;

$\mathrm{CE}_{\mathrm{it}}$ : Ratio of total outstanding balance to total assets of bank $i$ at time $t$.

The research also examines descriptive statistics to preliminarily analyze basic information from the sample.

To determine the correlation between dependent and independent variables, regression parameters are estimated for the model of determinants in two steps: (i) Selecting an appropriate regression model by comparing fixed effects model (FEM) and random effects model (REM) using the Hausman test (after the exclusion of Pooled OLS); and (ii) Analyzing regression model of factors affecting LLP. To conveniently regress panel data, the research utilizes Stata 11. 


\section{RESULTS AND DISCUSSION}

\subsection{Results:}

\section{Descriptive statistics}

For the period 2008-2012, LLP of the banks is at an average of $1.236 \%$ with standard deviation of $0.648 \%$. In the same year 2008, Oceanbank comes up with the lowest rate $(0.193 \%)$, whereas VCB has the highest rate $(3.702 \%)$.

\section{Table 2. Descriptive Statistics of Variables}

\begin{tabular}{|c|c|c|c|c|}
\hline Variable & Min & $\operatorname{Max}$ & Mean & Std. Dev. \\
\hline $\begin{array}{l}\text { Ratio of LLP to total outstanding balance } \\
\text { (LLP) }\end{array}$ & 0.193 & 3.702 & 1.236 & 0.648 \\
\hline Asset size (SIZE) & 6.298 & 8.702 & 7.598 & 0.573 \\
\hline Ratio of equity to total assets (ER) & 3.046 & 41.390 & 13.158 & 8.545 \\
\hline $\begin{array}{l}\text { Ratio of bad debt to total outstanding balance } \\
\text { (NP1) }\end{array}$ & 0.539 & 8.827 & 2.406 & 1.465 \\
\hline Ratio of bad debt to total assets (NP2) & 0.143 & 6.043 & 1.206 & 0.886 \\
\hline $\begin{array}{l}\text { Ratio of earnings before tax and provision to } \\
\text { total assets (CROA) }\end{array}$ & 0.078 & 5.640 & 1.901 & 1.059 \\
\hline $\begin{array}{l}\text { Ratio of total loan outstanding balance to total } \\
\text { assets (CE) }\end{array}$ & 15.610 & 94.422 & 52.163 & 14.262 \\
\hline Observations & \multicolumn{4}{|c|}{115} \\
\hline
\end{tabular}

Source: Data analysis by STATA

ER of the banks has a mean of $13.158 \%$ with quite high standard deviation of $8.545 \%$. While MHB in 2010 reveals the lowest ER at 3.046\%, WEB in 2008 shows the highest ER of up to $41.390 \%$ due to an increase in chartered capital from VND200 to 1,000 billion.

NP1 has a mean of $2.406 \%$, a minimum of $0.539 \%$ (NVB 2008) and a maximum of $8.827 \%$ (MHB 2010), whereas NP2 has a mean of $1.206 \%$, a minimum of $0.143 \%$ (ACB 2010) and a maximum of 6.043\% (PGBank 2012). 
CROA yields the results including a mean, min and max of $1.901 \%, 0.078 \%$ (MHB 2008 ) and $5.640 \%$ (Saigonbank 2010) respectively with standard deviation of $1.059 \%$.

CE reflects a mean of $52.163 \%$ and a high standard deviation (14.262\%). MDB in 2009 has the highest CE rate, being $94.422 \%$, but it also manifests itself as the bank with the lowest CE rate in 2010 (15.610\%), being subject to an increase in both chartered capital from VND1,000 billion to 3,000 billion and mobilized capital, but its outstanding balance does not increase much.

Correlation Matrix

Table 3 denotes the correlation coefficients between pairs of variables vary between 0.007 and 0.651 . In particular, the highest level is 0.651 , suggesting the correlation between SIZE and ER, but it is only within the average range (0.4 to 0.8$)$, thereby being regarded acceptable. In addition, the low correlation coefficients between pairs of independent variables further confirms the appropriateness of the studied model as the multicollinearity would scarcely happen when applying the regression model to the correlation between loan loss provision and the affecting factors.

Table 3. Correlation Matrix between Independent Variables

\begin{tabular}{ccccccc}
\hline & SIZE & ER & NP1 & NP2 & CROA & CE \\
\hline SIZE & 1.000 & & & & \\
ER & -0.651 & 1.000 & & & \\
NP1 & -0.048 & 0.007 & 1.000 & & & \\
NP2 & -0.073 & 0.008 & -0.051 & 1.000 & & \\
CROA & -0.145 & 0.294 & -0.027 & 0.098 & 1.000 & \\
CE & -0.021 & -0.091 & -0.102 & 0.439 & 0.307 & 1.000 \\
\hline
\end{tabular}

Source: Data analysis by STATA

Regression results with OLS, FEM, REM 
Table 4. Estimation of Factors in OLS, FEM and REM

\begin{tabular}{|c|c|c|c|c|c|c|}
\hline \multirow{2}{*}{$\begin{array}{c}\text { Independent } \\
\text { variable }\end{array}$} & \multicolumn{2}{|c|}{ Pooled OLS } & \multicolumn{2}{|c|}{ FEM } & \multicolumn{2}{|c|}{ REM } \\
\hline & Coef. & $\begin{array}{l}\text { Sig. } \\
(\mathbf{P}>|\mathbf{t}|)\end{array}$ & Coef. & $\begin{array}{l}\text { Sig. } \\
(\mathbf{P}>|\mathbf{t}|)\end{array}$ & Coef. & $\begin{array}{l}\text { Sig. } \\
(\mathrm{P}>|\mathbf{t}|)\end{array}$ \\
\hline SIZE & $0.6680 * * *$ & 0.000 & $0.5459 * * *$ & 0.001 & $0.6121 * * *$ & 0.000 \\
\hline ER & 0.0007 & 0.907 & -0.0086 & 0.260 & -0.0029 & 0.650 \\
\hline NP1 & 0.0365 & 0.181 & 0.0184 & 0.389 & 0.0229 & 0.280 \\
\hline NP2 & $0.4333 * * *$ & 0.000 & $0.3681 * * *$ & 0.000 & $0.3793 * * *$ & 0.000 \\
\hline CROA & $0.1053 * *$ & 0.012 & 0.0163 & 0.712 & 0.0567 & 0.150 \\
\hline $\mathrm{CE}$ & -0.0049 & 0.140 & $-0.0066^{*}$ & 0.087 & $-0.0053^{*}$ & 0.098 \\
\hline Cons & -4.4059 & 0.000 & -2.9724 & 0.038 & -3.7201 & 0.000 \\
\hline Observations & \multicolumn{2}{|c|}{115} & \multicolumn{2}{|c|}{115} & \multicolumn{2}{|c|}{115} \\
\hline R-Squared & \multicolumn{2}{|c|}{$60.92 \%$} & \multicolumn{2}{|c|}{$57.76 \%$} & \multicolumn{2}{|c|}{$57.08 \%$} \\
\hline$F(22,86)$ & \multicolumn{6}{|c|}{5.16} \\
\hline p-value & \multicolumn{2}{|c|}{0.0000} & \multicolumn{2}{|c|}{0.0000} & \multicolumn{2}{|c|}{0.0000} \\
\hline
\end{tabular}

$*, * *$ and $* * *$ denote significance at $10 \%, 5 \%$ and $1 \%$ respectively

Source: Data analysis by STATA

Pooled OLS may explain $60.92 \%$ of the change in the factors affecting LLP. Table 4 indicates that variables SIZE, NP2, and CROA have significance at $1 \%$ and positively affect LLP rate.

However, for the estimation with pooled OLS, cross-sectional data, in terms of space and time, are too closely bound while regression coefficients remain unchanged, disabling the model to successfully reflect the impact of the difference of each bank, which leads to drastic reduction in the impact of independent variables on the dependent one and results inconsistent with actual conditions. Therefore, the F test is performed to detect fixed effects of each bank in the model. Results presented in Table 4 suggest that Pooled OLS is not an appropriate technique due to the existence of fixed effects of each bank $[F(22.86)=5.16$ and $p$ - value $=0.000]$. Nevertheless, it should be 
early to confirm the suitability of FEM. The Hausman test is used to make right selection between FEM and REM.

Hausman test

Table 5. Hausman Test Results

\begin{tabular}{lccccc}
\hline & \multicolumn{2}{c}{ Regression with FEM } & \multicolumn{2}{c}{ Regression with REM } & \multirow{2}{*}{ Dif. lev (b-B) } \\
\cline { 2 - 4 } & Reg. coef. (b) & Sig. & Reg. coef. (B) & Sig. & \\
\hline SIZE & 0.5459 & 0.001 & 0.6121 & 0.000 & -0.0661 \\
ER & -0.0086 & 0.260 & -0.0029 & 0.650 & -0.0056 \\
NP1 & 0.0184 & 0.389 & 0.0229 & 0.280 & -0.0046 \\
NP2 & 0.3681 & 0.000 & 0.3793 & 0.000 & -0.0112 \\
CROA & 0.0163 & 0.712 & 0.0567 & 0.150 & -0.0404 \\
CE & -0.0066 & 0.087 & -0.0053 & 0.098 & -0.0013 \\
H & & & & \\
chi2(6): 64,04 & & & & \\
Prob $>$ chi2: 0.0000 & & & & \\
\hline
\end{tabular}

Source: Data analysis by STATA

The results show that the FEM is appropriate for the research since Prob $>$ chi $2=$ $0.0000<5 \%$ and the significance is at $1 \%$.

\section{Regression results with FEM}

Based on FEM selected as the research model, regression parameters are estimated. Regression coefficient (Coef.) is coefficient of impact of independent variables on the dependent one. $\mathrm{P}>|\mathrm{t}|$ indicates statistical significance of independent variables. The lower this value, the safer the independent variables included in the model, especially at levels below $5 \%$.

The results in Table 5 indicate that SIZE and NP2 are statistically significant $(<$ $5 \%$ ) and thereby could be persuasively included in the model. CE at $8.7 \%$ (a level higher than $5 \%$ but not too much) could also be included in the model. However, sign of this variable is against the expected one. The remaining variables (ER, CROA and NP1) are eliminated due to a lack of statistical significance. 
Table 6. Regression Results with FEM

\begin{tabular}{cccc}
\hline Variable & Reg. coef. & t-test & Sig. $(\mathbf{P}>|\mathbf{t}|)$ \\
\hline SIZE & 0.5459 & 3.28 & 0.001 \\
ER & -0.0086 & -1.13 & 0.260 \\
NP1 & 0.0184 & 0.87 & 0.389 \\
NP2 & 0.3681 & 8.60 & 0.000 \\
CROA & 0.0163 & 0.37 & 0.712 \\
CE & -0.0066 & -1.73 & 0.087 \\
Cons & -2.9724 & -2.11 & 0.038 \\
\hline
\end{tabular}

Observations: 115

$\mathrm{R}^{2}: 0,5776$

F-test: 0,0000

Residual test $\left(u_{-} i=0\right): 0.0000$

Source: Data analysis by STATA

Regression function with FEM:

$$
L L P_{i t}=\alpha_{i}+0,5459 S_{Z I Z E_{i t}}+0,3681 N P 2_{i t}-0,0066 C E_{i t}
$$

\subsection{Discussion:}

The model can possibly explain $57.76 \%$ of the impact of independent variables on LLP. The research shows that impacts of the factors on LLP, in order of strength, are as follows:

Asset size (SIZE): The larger the bank assets, the higher the LLP becomes, which is compliant with hypothesis $\mathrm{H} 1$. The research results are consistent with those by Chen et al. (2005), Anandarajan et al. (2005) and Ashour (2011). Two banks with chartered capital of above VND20,000 billion are VCB and BIDV, which come up with the highest LLP, ranging from $2.712 \%$ to $3.702 \%$. In other words, larger assets result in higher loan loss provisions. In Vietnam, large banks, thanks to their huge equity, are not placed under pressure to raise capital and have motives for sending signals to the market concerning increased credit quality due to adequate LLP, especially when bad debts are causing worries. In contrast, small-sized banks, because of modest equity and 
pressure for more capital, have motives to increase equity in several ways, such as keeping low loan loss provisions to increase earnings.

Bad debt (NP2): The level of loan loss provisions is partly determined by bad debt, so bad debt is positively correlated with LLP. The research results, which suggest that banks with higher ratio of bad loans to total assets keep greater LLP, are compliant with both expected signs and hypothesis H3 and the studies by Hasan \& Larry (2003) and Perez et al. (2011). These results explain the agency relationship between bank managers (as agent, representing the shareholders) and creditors (depositors as principal). To reduce incurred agency costs (due to higher dividends), the creditors require restrictions, such as control over the quality of lending operations by establishing full provisions.

Coefficient of financial risk (CE): $\mathrm{CE}$ is revealed to be negatively correlated with LLP (opposite to the expected signs in H5) and this finding is similar to empirical results established by Bikker \& Metzemakers (2004), and Moyer (1990). However, studies by Beatty et al. (1995) and Hasan \& Wall (2004) find that CE has positive impact. Apart from this, Ashour (2011) rejects this hypothesis in his study due to lack of statistical significance. Data used for the research are based bank financial statements, which have been audited without considering differences in accounting policies between banks regarding loan classification and establishment of loan loss provisions based on Decision No. 493/2005/QĐ-NHNN assessed as inadequate. Therefore, the results demonstrate that small-sized banks, due to pressure for bigger equity, tend to adopt accounting policies that can reduce the costs of loan loss provisions.

The research preliminarily provides empirical evidence of agency theory and signaling theory applied to the field of LLP accounting of commercial banks. According to Morris (1987), agency and signaling theories do not contradict each other but, on the contrary, act in concert to explain reasonable behavior in selection of accounting policies. Specifically, information asymmetry in signaling theory is implicitly understood to create monitoring costs of agency theory. Large-sized banks not only long to signal the establishment of adequate LLP but also assure bank's creditors of remarkable ability to cope with credit risks. Banks with high ratios of bad debts tend to keep high LLP to reduce agency costs. 
Ultimately, comparing CEs should be taken into account under the condition that the comparability of accounting statistics provided by the banks on the basis of SBV's guidance on debt classification and LLP establishment is ensured.

\section{CONCLUSIONS}

This quantitative research aims at testing the theories applied to different socioeconomic conditions as well as various periods in order to help confirm application of background theories to accounting research in Vietnam. However, the research results in comparison with those of previous studies need be carefully considered in the context of Vietnam. In particular, IAS 39 requires that in determining the LLP banks follow two steps: (i) identify loan loss and (ii) measure the loss of loans. Thus, the more different the LLP-related accounting principles between countries, the more limited the comparisons become.

Limitations of the research are: (1) variables included in the model could not fully explain loan loss provisions of commercial banks because many factors not being included in the model could affect bank LLP; and (2) variables in the model are merely financial ones. Hence, further studies may adopt variables concerning managerial activities, which could help explain better the establishment of LLP.

\section{IMPLICATION AND POLICY RECOMMENDATIONS}

First, the results suggest that coefficient of financial risk has a negative correlation with LLP or contradicts the expected signs of H5. This finding is from the fact that the data used for testing are banks' financial statements for the period 2007-2012 when loan classification and establishment of LLP complied with Decision 493/2005/QĐNHNN. Realizing inadequacies of Decision 493, SBV has issued Circular 02/2013/TTNHNN as a replacement, which has yet to take effect so far.

Next, the system of accounting standards set by the Ministry of Finance does not include standards for financial instruments, which are essential in accounting for loan supply and loan loss provisions.

Additionally, loan classification relies on internal credit rating systems adopted by commercial banks. Results from a survey of the Vietnam's banking sector in 2013 by KPMG indicate that most Vietnam's commercial banks have been applying a similar internal credit rating model that has been deployed several years ago. 
Last, asset size, a portion of which depends on bank chartered capital, positively affects LLP. Although specific solutions are not to be stipulated, a few recommendations based on the research results can be submitted as below:

- Ministry of Finance should consider the issuance of accounting standards on financial instruments, especially provisions on financial loss accounting (including loan transactions). These would provide commercial banks with a basis for identifying loan losses and measuring them exactly and reasonably.

- SBV should promptly and formally apply Circular 02/2013/TT-NHNN on loan classification and provisioning standards as a substitute for Decision 493/2005/QĐNHNN to bring these operations closer to international practices.

- Commercial banks expeditiously improve the credit rating system as the basis for loan loss identification and measurement. Furthermore, these banks should improve their own financial capability to readily carry out Circular 02/2013/TT-NHNN in the time to come

\section{References}

Ahmed, A.S., C. Takeda \& S. Thomas (1999), "Bank Loan Loss Provisions: A Reexamination of Capital Management, Earnings Management and Signaling Effects", Journal of Accounting and Economics, 28(1): 1-25.

Anandarajan, A., I. Hasan \& A.L. Vivas (2005), "Loan Loss Provision Decisions: An Empirical Analysis of the Spanish Depository Institutions”, Journal of International Accounting, Auditing and Taxation, 14 (1): 55-77.

Ashour, M.O. (2011), "Banks Loan Loss Provision Role in Earnings and Capital Management Evidence from Palestine", dissertation for the degree of master in accounting finance, Islamic University Gaza.

Beatty, A., S.L. Chamberlain \& J. Magliolo (1995), "Managing Financial Reports of Commercial Banks: The Influence of Taxes, Regulatory Capital, and Earnings", Journal of Accounting Research, 33(Autumn): 231-261.

Beaver, W., C. Eger, S. Ryan \& M. Wolfson (1989), "Financial Reporting, Supplemental Disclosures and Bank Share Prices", Journal of Accounting Research, 27(2): 157-178.

Beaver, W. \& E. Engel (1996), "Discretionary Behavior with Respect to Allowances for Loan Losses and the Behavior of Security Prices", Journal of Accounting and Economic, 22(1-3): 177-206. 
Bikker, J.A., P.A.J. Metzemakers (2005), "Banks Provisioning Behaviour and Procyclicality", Journal of International Financial Markets, Institutions \& Money, 15(2): 141-157.

Chen, G.T., K.H. Chung \& S.E. Gazzar (2005), "Factors Determining Commercial Banks' Allowance for Loan Losses", Commercial Lending Review, 20(2): 25-47.

Collins, J.H., D. Shackelford \& J.M. Wahlen (1995), "Bank Differences in the Coordination of Regulatory Capital, Earnings, and Taxes”, Journal of Accounting Research, 33(2): 263-291.

Fudenberg, D. \& J. Tirole (1993), “A Theory of Income and Dividend Smoothing Based on Incumbency Rents", Journal of Political Economy, 103(1): 75-93.

Gray, R.P. \& F.L. Clarke (2004), “A Methodology for Calculating the Allowance for Loan Losses in Commercial Banks", ABACUS, 40(3).

Hasan, I. \& L.D. Wall (2004), "Determinants of the Loan Loss Allowance: Some Cross-Country Comparisons", The Financial Review, 39(1): 129-152.

Hempel, G.H. \& D.O. Simonson (2001), Quản trị ngân hàng, NXB Thống Kê, Hà Nội.

Jensen, M. \& W.H. Meckling (1976), "Theory of the Firm: Managerial Behavior, Agency Costs and Ownership Structure”, Journal of Financial Economics, 3(4): 305-360.

Kanagaretnam, K., G.J. Lobo \& D.H. Yang (2005), "Determinants of Signaling by Banks through Loan Loss Provisions”, Journal of Business Research, 58 (3): 312-320.

Kim, D. \& A.M. Santomero (1993), "Forecasting Required Loan Loss Reserves", Journal of Economics and Business, 45: 315-329.

KPMG (2013), “Khảo sát về ngành ngân hàng Việt Nam năm 2013”, retrieved from $<$ http://tcqt.proboards.com/thread/281/share-vietnam-banking-survey-2013> on June 30, 2014.

Leventis, S., P.E. Dimitropoulos \& D.A. Anandarajan (2012), "Signalling by Banks Using Loan Loss Provisions: The Case of the European Union", Journal of Economic Studies, 39(5): 604618.

Levinthal, D. (1988), “A Survey of Agency Models of Organizations”, Journal of Economic Behavior \& Organization, 2: 153-185.

Ma, C.K. (1988), "Loan Loss Reserves and Income Smoothing: The Experience in the U.S. Banking Industry", Journal of Business Finance \& Accounting, 15(4): 487-497.

MacDonald, S.S. \& T.W. Koch (2006), Management of Banking, 6th edition, Thomson South Western.

Mohd Yaziz Bin Mohd Isa (2011), "Determinants of Loan Loss Provisions of Commercial Banks in Malaysia", presented at 2nd International Conference on Business and Economic Research (ICBER), March 14-15, 2011, Langkawi Kedah, Malaysia.

Morris, R.D. (1987), "Signalling, Agency Theory and Accounting Policy Choice", Accounting and Business Research, 18(69): 47-65. 
Moyer, S.E. (1990), "Capital Adequacy Ratio Regulations and Accounting Choices in Commercial Banks", Journal of Accounting and Economic, 13: 123-154.

Ngô Xuân Thanh (2012), “Thách thức tái cơ cấu hệ thống ngân hàng thương mại Việt Nam”, Tài chính, retrieved from <http://tapchitaichinh.vn/Nghien-cuu-dieu-tra/Thach-thuc-tai-co-cau-hethong-ngan-hang-thuong-mai-Viet-Nam/14015.tctc> on Nov. 302012.

Nguyễn Thị Mùi (2012), “Thực trạng nợ xấu tại các ngân hàng thương mại Việt Nam và giải pháp tháo gỡ", Tài chính (11), retrieved from <http:/www.tapchitaichinh.vn/Trao-doi-Binhluan/Thuc-trang-no-xau-tai-cac-ngan-hang-Viet-Nam-va-giai-phap-thao-go/16290.tctc $>$ on Nov. 30, 2012.

Nguyễn Thị Thu Hiền \& Vũ Hữu Đức (2013), "Phân tích báo cáo tài chính các ngân hàng thương mại Việt Nam giai đoạn 2006-2011”, Working paper CS-2010-21, University of Economics HCMC.

Perez, D., V.S. Fumas \& J. Saurina (2008), "Earnings and Capital Management in Alternative Loan Loss Provision Regulatory Regimes”, European Accounting Review, 17(3): 423-445.

Sutton, M.H. (1997), “Current Developments in Financial Reporting”, presented at the 1997 Conference of Banks and Savings Institutions of the American Institute of Certified Public Accountants, Washington, D.C.

Wall, L.D. \& T.W. Koch (2000), "Bank Loan-Loss Accounting: A Review of Theoretical and Empirical Evidence”, Economic Review, 85(2): 1-16.

Wahlen, J.M. (1994), "The Nature of Information in Commercial Bank Loan Loss Disclosures", The Accounting Review, 69(3): 456-480.

Yeh, T. (2010), "Bank Loan Loss Provision Decisions: Empirical Analysis of Taiwanese Banks", Journal of Financial Services Marketing, 14(4): 278-289. 